Journal of Engineering Sciences, Assiut University, Vol. 35, No. 4, pp. 1009-1021, July 2007

\title{
ESTIMATION OF STRESS AND STRAIN LEVELS INDUCED BY BLASTING VIBRATIONS USING MEASURED PARTICLE AND PROPAGATION VELOCITIES AT BANI KHALID QUARRY
}

\section{Elseman I. Abdel-Rasoul and}

Associate Professor, Mining and Metallurgical Eng. Dept., Faculty of Engineering, Assiut University, elseman1@yahoo.com

\author{
Awad A. Omran \\ Professor, Geology Department, Faculty of Science, Assiut University, \\ e-mail: awaomran@yahoo.com
}

(Received June 17, 2007 Accepted July 4, 2007)

Quarry blasting operations are necessary to supply raw materials; nevertheless they produce ground vibration stresses in the foundations of the nearby structures and may affect their stability. Subsequently, estimation of the stress-strain levels can help the engineers to evaluate safety possibilities of the high wall slopes or the nearby structures. In the present study, shallow seismic refraction surveys have been carried out in Bani Khalid quarry to determine the velocity of the compression and shear waves of the quarry area. These seismic wave velocities have been used to identify the dynamic elastic constants such as Poisson's ratio, modulus of elasticity, and shear modulus. Ground vibration measurements, another set of field measurements, include recording of the three mutually perpendicular components of the peak particle velocities induced by the blasting operations in the quarry. The results of these measurements and calculations have been employed to estimate the normal and shear stresses and strains induced by the quarry blasting operations.

KEYWORDS: Stress and strain, bench blasting, ground vibrations, seismic waves, and elastic constants.

\section{INTRODUCTION}

Rock blasting is essential to separate, fragment, and displace rocks and mineral ores needed to supply raw materials for many industries. Ground vibrations are undesirable but unavoidable output of the blasting process. If the level of the ground vibrations exceeds certain levels, it may cause problems ranging from annoyance to severe damage to nearby structures. Hence, blasting engineers have to make blast designs that satisfy their production plans and at the same time do not annoy neighbors or damage their properties. In addition, care has to be taken not to cause stability problems to high wall slopes and/or roofs at the mine $[1,2]$. 
Ground vibration measurement and evaluation have gone through different forms including energy ratio, particle displacement, velocity, or acceleration. Finally, the researchers have settled on the particle velocity as the best descriptor of the blasting ground vibrations [1-3]. The reason is that particle velocity has a direct relation to strains and stresses which are the measures used to judge the capacity of materials. From the level of the applied vibration stress and the strength of the material, it can be determined if they are allowable or not [2].

The elastic properties of rock materials are either evaluated from the conventional geotechnical methods or the in-situ geophysical measurements. Shallow geophysical techniques are considered as one of the accurate and cost effective methods used in engineering site characterization of the rock mass. They are an alternative means of the conventional geotechnical ones, which are sometimes tedious and very expensive $[4,5]$. The kinetic elastic moduli of the surface and shallow layers can be identified using the compression and shear waves velocities and the material bulk densities as well. The rock mass quality depends mainly upon the material elastic moduli, which include shear modulus, Poisson's ratio and Young's modulus [2, 4-10].

Burgher [8] has measured longitudinal and shear wave velocities as well as particle velocities in the Golden Sunlight mine in Montana. From these measurements, he calculated the stresses and strains. His study aimed at maintaining high wall stability and integrity at the mine. On the other hand, Tealeb et al [9-11] carried out an intensive monitoring of blasting ground vibrations and records have been collected during a long period (1997-2000), to estimate the blasting stresses induced by blasts in the limestone quarries of the National Cement Company at the $15^{\text {th }}$ of May City, Helwan, Egypt. They claimed that the estimated stress levels were very high and these high stress levels, caused significant damage to the buildings of the $15^{\text {th }}$ of May City.

\section{STRESS AND STRAIN CALCULATION}

In the near field of a detonating blast hole, the wave front is curved and the calculation of the stresses and strains is complicated. In the far field (at distances greater than 15 meter from the blast hole), the wave front can be considered planar (i.e. particles move parallel to the direction of propagation of the longitudinal wave). Also the wave is assumed to be sine wave. These assumptions simplify the method of calculation and these calculations are accurate enough for engineering applications. Dowding explains the method of calculation of strain and stress as follow [2]:

\section{Compressive Stresses and Strains:}

$$
\begin{aligned}
& C_{p}=(E / \rho)^{1 / 2} \\
& \varepsilon=\stackrel{\circ}{\mathrm{u}} /-C_{p} \\
& \sigma=\rho C_{p} \stackrel{\circ}{\mathrm{u}} \\
& E=\sigma / \varepsilon
\end{aligned}
$$

Where:

$$
\begin{aligned}
& \varepsilon=\text { strain } \\
& \sigma=\text { stress } \\
& \stackrel{\circ}{\mathrm{u}}=\text { longitudinal particle velocity }
\end{aligned}
$$


$\rho=$ mass density of the rock

$\mathrm{E}=$ modulus of elasticity

$\mathrm{C}_{\mathrm{p}}=$ longitudinal wave velocity.

\section{Shear Stresses and Strains:}

Where:

$$
\begin{aligned}
& \mathrm{C}_{\mathrm{s}}=(\mathrm{G} / \rho)^{1 / 2} \\
& \gamma=\stackrel{\circ}{\mathrm{u}}_{\mathrm{s}} /-\mathrm{C}_{\mathrm{s}} \\
& \tau=\rho \mathrm{C}_{\mathrm{s}} \stackrel{\circ}{\mathrm{u}}_{\mathrm{s}} \\
& \mathrm{G}=\tau / \gamma
\end{aligned}
$$

$$
\begin{aligned}
& \gamma=\text { shear strain } \\
& \tau=\text { shear stress } \\
& \stackrel{\mathrm{u}}{\mathrm{s}}_{\mathrm{s}}=\text { transverse (shear) particle velocity } \\
& \mathrm{C}_{\mathrm{s}}=\text { shear wave velocity } \\
& \rho=\text { mass density of rock } \\
& \mathrm{G}=\text { modulus of rigidity }
\end{aligned}
$$

The longitudinal and shear wave propagation velocities (in three dimensions) are related to the elastic constants by the following equations $[6,7]$ :

While:

$$
\left(C_{p}\right)^{2}=(1-v) E /[(1+v)(1-2 v) \rho]
$$

$$
\left(C_{s}\right)^{2}=E /[2(1+v) \rho]
$$

With some manipulation between equations (9) and (10), we can find the following equation for calculating Poisson's Ratio, $\boldsymbol{v}$ :

And

$$
v=\left[1-2\left(C_{s} / C_{p}\right)^{2}\right] /\left[2-2\left(C_{s} / C_{p}\right)^{2}\right]
$$

$$
\mathrm{C}_{\mathrm{p}} / \mathrm{C}_{\mathrm{s}}=[(1-v) /(1 / 2-v)]^{1 / 2}
$$

In case of $v=0.25$, the $\mathrm{C}_{\mathrm{p}} / \mathrm{C}_{\mathrm{s}}$ ratio is equal to 1.7 . Also $\mathrm{E}$ and $\mathrm{G}$ are related by the following equation:

$$
\mathrm{G}=\mathrm{E} / 2(1+v)
$$

Coats [7] concluded that using equation (1) (assuming one dimensional wave propagation) would produce an answer about 5\% higher than using equation (9) (assuming three dimensional wave propagation) for calculating seismic velocities. He claimed that this difference is not significant when considering the difficulty of determining the effective $\mathrm{E}$ that would apply to a rock mass.

\section{AIM OF THE RESEARCH}

In the present study, shallow seismic refraction surveys have been carried out in Bani Khalid quarry to determine the velocity of compression and shear waves at the quarry area. From these seismic wave velocities, dynamic elastic constants such as Poisson's ratio, modulus of elasticity (Young's modulus), and shear (rigidity) modulus can be calculated. Ground vibration measurements, another group of field measurements, have been carried out and include measurement of the three mutually perpendicular components of the peak particle velocities induced by the blasting operations in the 
quarry. From the results of these measurements and calculations, normal and shear stresses and strains can be estimated.

\section{BANI KHALID QUARRY}

Bani Khalid quarry is situated on the eastern bank of the River Nile (100-500 m inward), four kilometers south east of Samalout town, Minia. It is the main source of limestone for the Egyptian Iron and Steel Company. It is about 190 kilometers south of the Iron and Steel Company in Helwan. Bani Khalid Village lies on the northern border of the quarry while Dier Gebel-Eltair Village lies on the southern border (Figure 1). The numulitic limestone of the quarry belongs to the middle Eocene. The productive limestone layers are divided into four layers. From top down, layers I and II have a volumetric weight of $2 \mathrm{t} / \mathrm{m}^{3}$ and their thickness ranges from $0-21 \mathrm{~m}$; followed by layers III and IV, which have a volumetric weight of $2.2 \mathrm{t} / \mathrm{m}^{3}$ and thickness of about $15 \mathrm{~m}$. On the top, small thickness $(0-1.5 \mathrm{~m})$ of loose overburden has a volumetric weight of 1.8 $\mathrm{t} / \mathrm{m}^{3}$. The absolute ground water level is at $31 \mathrm{~m}$ (the level of the quarry bottom). The compressive strength of the quarry limestone ranges from $170-600 \mathrm{~kg} / \mathrm{cm}^{2}$ [12].

\section{EXPERIMENTAL PROCEDURE}

\section{Seismic Refraction Survey:}

A shallow seismic refraction survey at the area between the upper quarry face and the northern borders of Dier Gebel-Eltair Village has been carried out. In this operation, a sledge hammer has been used as a source of the compression waves by repeated impacts on a metal striker plate. The shear wave source consists of a hammer blow on the side of a block, which is held in firm contact with the Earth by the weight of a heavy vehicle. The block has been struck on the opposite side to obtain the opposite polarity that adds the SH-wave effects (Sheriff and Geldart, 1982) [5]. The compression waves were detected by normal geophones, while shear waves were detected by using the horizontal geophones.

The employed profiling technique, along which the shot-point-geophone array is extended, was in the form of in-line offset spreads doubled by forward and reverse shooting. The refraction seismic measurements involved eight layouts that were distributed approximately parallel and perpendicular to the upper bench face and the northern border of Dier Gebel-Eltair Village. The geophone cable was about $120 \mathrm{~m}$ in length (inter-geophone spacing was 10 or $5 \mathrm{~m}$ ). The arrival times of stacking repeated signals were acquired by using the seismic system model ES-1225 12-channel digital enhancement exploration seismograph, manufactured by EG\&G Geometrics [13]. Swave records are usually displayed in the same manner as P-wave records. A sample of the recorded seismograms is given in Figure 2. 


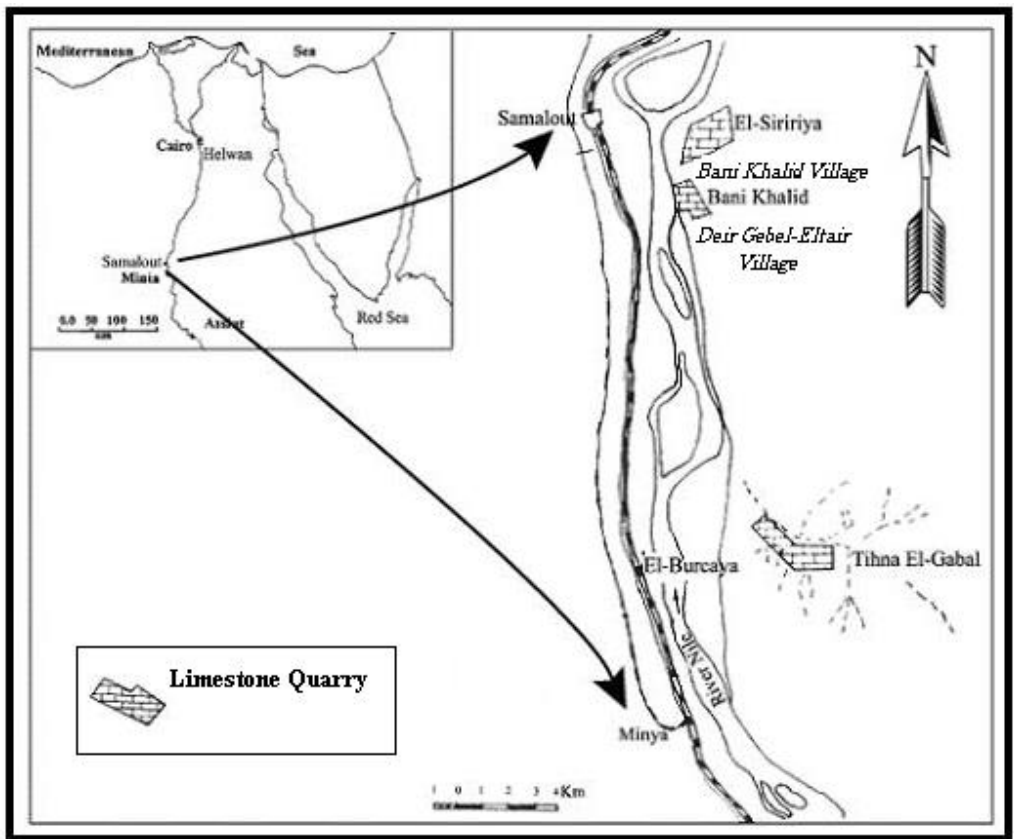

Fig. 1: Key map for Bani Khalid quarry.
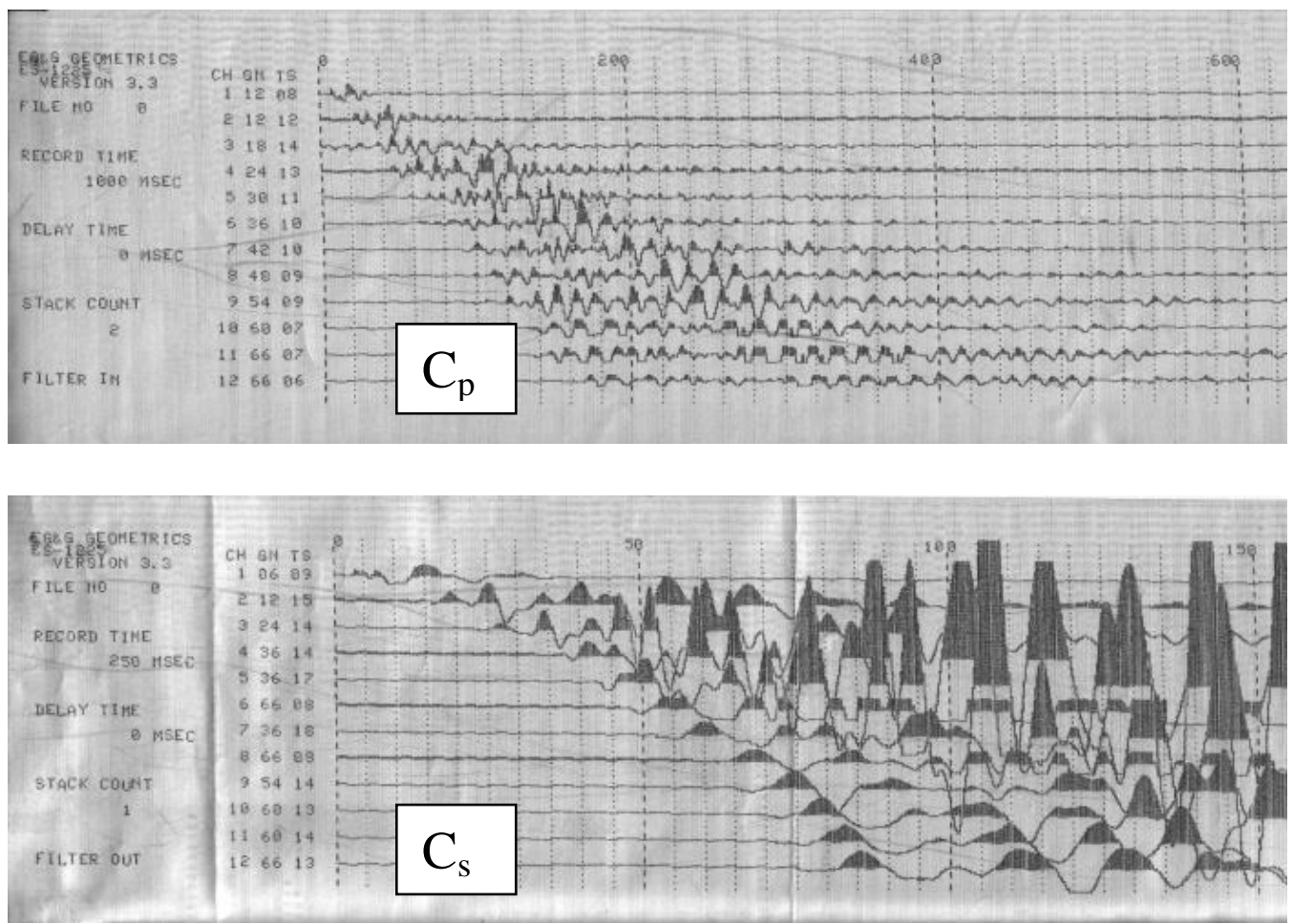

Fig. 2: A sample of the geophone recorded seismograms for arrival times using EG\&G system. 


\section{Measurement of the Ground Vibrations Peak Particle Velocity:}

Measurement of the ground vibrations has been carried out using Geosonics SSU 2000 DK-system, 10 micro-seismographs, two data transfer cases, and two manual buttons $[14,15]$. The seismographs have been oriented toward the center of the blast, leveled, and fixed at the recording station. The recording stations have been selected close to the foundations of the buildings of the northern border of Dier Gebel-Eltair Village. The detailed procedure steps can be found in other references [14-17]. Figure 3 provides an example for the obtained seismograms from the Geosonics system.

\section{ANALYSIS AND DISCUSSION OF RESULTS}

Bani Khalid quarry has two benches. The height of the lower bench is about $10 \mathrm{~m}$ while the height of the upper bench varies from 6 to $20 \mathrm{~m}$ depending on the topography. Blast hole diameter for the upper bench is $105 \mathrm{~mm}$ and that of the lower bench is $95 \mathrm{~mm}$. Other bench parameters include: burden $(\mathrm{B})=$ spacing $(\mathrm{S})=4 \mathrm{~m}$, stemming length $(\mathrm{T})=2-3 \mathrm{~m}$, sub drilling $(\mathrm{J})=1.5-2.0 \mathrm{~m}$, and number of rows $=2-4$. The main explosive charge is ANFO, and Ammonia Gelatin Dynamite has been used as priming and boosting charge. The specific charge is about $0.5 \mathrm{~kg} / \mathrm{m}^{3}$.

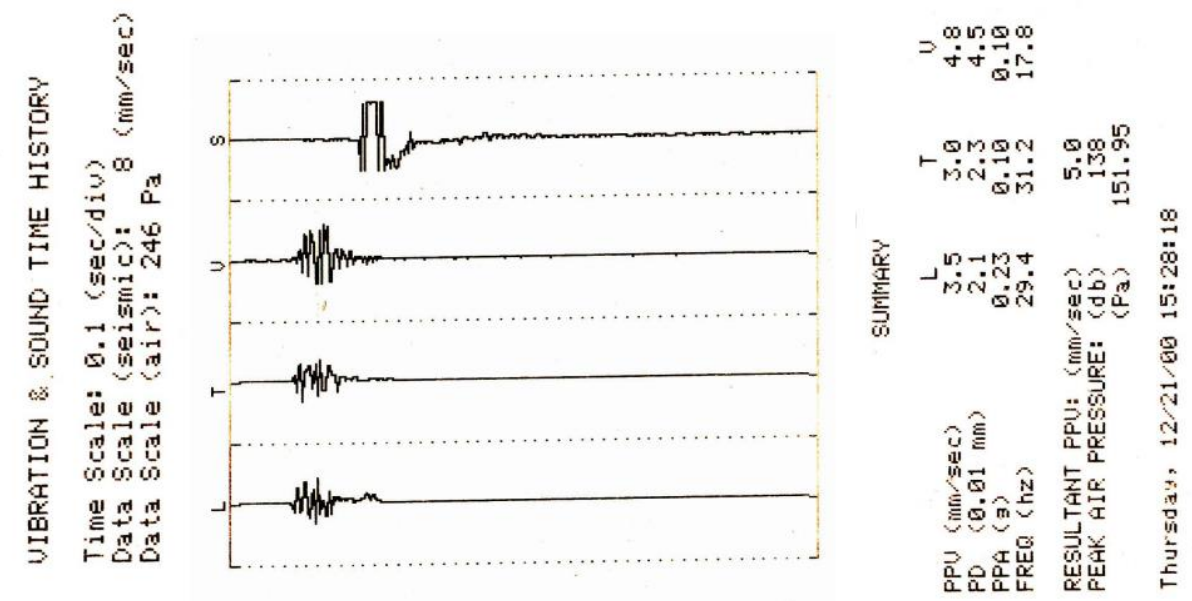

Fig. 3: A sample of the recorded seismograms for obtaining peak particle velocities using Geosonics system.

Thirty one records have been carried out during the years 2000-2001. The geophone number $(\mathrm{G} \#)$; distances from the recording stations to the center of the blast (D); the weight of charge per delay (W); the air blast (sound) level; the components of the peak particle velocity (PPV): longitudinal (L), transverse (T), and vertical (V), vector sum $(\mathrm{R})$; calculated square (SD2) and cube root (SD3) scaled distances are recorded in a table for each blast. Table $\mathbf{1}$ is an example of such tables. 
The records of the amplitudes of the ground vibration peak particle velocity have

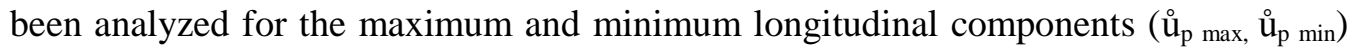
from both the upper and lower benches. Also records of the amplitudes of the ground vibration peak particle velocity have been analyzed for the maximum and minimum

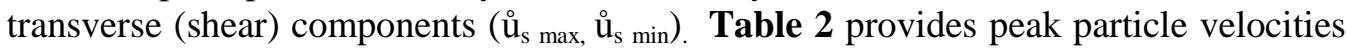
from upper and lower bench blasts.

\section{Seismic Survey:}

The first arrival times were picked from all seismic records at each geophone location, topographically corrected and then fed into the computer. Using a package of software (EG\&G Geometrics, 1986) [13], the data were processed and partially interpreted. This included the plotting of time-distance curves, fitting them with straight-line segments and evaluating the apparent velocity, thickness, boundary dip angle and finally the true velocity (compression " $\mathrm{C}_{\mathrm{p}}$ " or shear " $\mathrm{C}$ ") of the subsurface model layers using the intercept time method. The detailed interpretation and correlation between the obtained seismic velocities in the study area reveal three seismic layers.

The determined compression $\left(\mathrm{C}_{\mathrm{p}}\right)$ and shear $\left(\mathrm{C}_{\mathrm{s}}\right)$ wave velocities of the three layers are represented in Table 3. The velocity values of the surface layer range between 1612 and $1661 \mathrm{~m} / \mathrm{sec}$ for $\mathrm{C}_{\mathrm{p}}$ and between 1009 and $1038 \mathrm{~m} / \mathrm{sec}$ for $\mathrm{C}_{\mathrm{s}}$. The velocity of the second layer ranges from 2480 to $2838 \mathrm{~m} / \mathrm{sec}$ for $\mathrm{C}_{\mathrm{p}}$ and from 1649 to $1715 \mathrm{~m} / \mathrm{sec}$ for $\mathrm{C}_{\mathrm{s}}$. Finally, the last layer velocities range from 4380 to $4604 \mathrm{~m} / \mathrm{sec}$ for $\mathrm{C}_{\mathrm{p}}$ and from 2933 to $3081 \mathrm{~m} / \mathrm{sec}$ for $\mathrm{C}_{\mathrm{s}}$.

The average thickness of layer 1 and layer 2 has been found to be $7.8 \mathrm{~m}$ and $12.25 \mathrm{~m}$ respectively. Layer 1 , more or less, represents the layers geologically classified as layers I and II of bench 1 while layer 2 represents the geologically classified layers as layer III and IV of bench 2. The thickness of layer 1 has wide variation from 4.5 to 12.2 due to the change of topography. Layer 3 , is the bottom layer and its thickness has not been determined due to the short length of the spread of the seismic profile.

\section{Calculation of field dynamic elastic constants:}

Maximum and minimum magnitudes of Poisson's ratio have been calculated for the three seismic layers using maximum and minimum magnitudes of $\mathrm{C}_{\mathrm{p}}$ and $\mathrm{C}_{\mathrm{s}}$ for each layer. Maximum and minimum magnitudes of Young's modulus have been calculated for the three seismic layers based on the assumption of one dimensional propagation (using equation (1)). Also maximum and minimum magnitudes of Young's modulus have been calculated for the three seismic layers based on the assumption of three dimensional wave propagation (using equation (9)). The calculated Young's modulus based on 1-D wave propagation is of higher magnitudes than those based on 3-D wave propagation by magnitudes ranging from 2 to $13 \%$. Higher percentages are associated with higher Poisson's ratios. 
Table 1: Summary of the data of blast \# 4, carried out on the $3^{\text {rd }}$ of December 2000.

Date : $12 / 3 / 2000$

Time : $15: 56$

Max. Charge Weight (w)/delay $=460 \mathrm{~kg}$, $\mathrm{w}^{1 / 2}=21.45 \mathrm{~kg}^{1 / 2}, \mathrm{w}^{1 / 3}=7.72 \mathrm{~kg}^{1 / 3}$

Blast Location: Upper bench

Firing Method: Electric caps + Detonating cord

Total charge $(\mathrm{W})=2300 \mathrm{~kg}$

Total Number of Blast holes: 20

Depth of b. h. $=16.5 \mathrm{~m}$,

$\mathrm{B}=4 \mathrm{~m}, \mathrm{~S}=4 \mathrm{~m}, \mathrm{~T}=3 \mathrm{~m}, \mathrm{~J}=2 \mathrm{~m}$, Dia. $=105 \mathrm{~mm}, \alpha=90^{\circ}$

\begin{tabular}{|c|c|c|c|c|c|c|c|}
\hline \multirow{2}{*}{ G \# } & \multirow{2}{*}{$\mathrm{D}, \mathrm{m}$} & \multirow{2}{*}{ SD2 } & \multirow{2}{*}{ SD3 } & \multirow{2}{*}{$\begin{array}{l}\text { Sound } \\
\text { Level }\end{array}$} & \multicolumn{3}{|c|}{$\mathrm{PPV}, \mathrm{mm} / \mathrm{sec}$} \\
\hline & & & & & $\mathrm{L}$ & $\mathrm{T}$ & $\mathrm{V}$ \\
\hline 2547 & 268.0 & 12.5 & 34.72 & & $\begin{array}{c}4.0 \\
\text { f } 29.4 \\
\text { R } 4.8\end{array}$ & $\begin{array}{c}3.0 \\
35.7\end{array}$ & $\begin{array}{r}4.0 \\
38.4\end{array}$ \\
\hline 4665 & 299.0 & 13.94 & 38.73 & $\begin{array}{c}138 \mathrm{~dB} \\
153.95 \mathrm{pa}\end{array}$ & \begin{tabular}{l}
\multicolumn{2}{c}{3.0} \\
f 35.7 \\
R 4.5
\end{tabular} & $\begin{array}{c}3.0 \\
33.3\end{array}$ & $\begin{array}{c}3.5 \\
35.7\end{array}$ \\
\hline 4663 & 222.0 & 10.35 & 28.76 & $\begin{array}{c}137 \mathrm{~dB} \\
137.96 \mathrm{pa}\end{array}$ & $\begin{array}{c}7.6 \\
\text { f } 38.4 \\
\text { R } 9.9\end{array}$ & $\begin{array}{c}8.1 \\
45.4\end{array}$ & $\begin{array}{c}6.8 \\
29.4\end{array}$ \\
\hline 4664 & 257.0 & 11.98 & 33.29 & $\begin{array}{c}140 \mathrm{~dB} \\
187.94 \mathrm{pa}\end{array}$ & \begin{tabular}{c}
\multicolumn{1}{c}{11.9} \\
f 45.4 \\
R 12.1
\end{tabular} & $\begin{array}{c}9.1 \\
41.6\end{array}$ & $\begin{array}{c}8.8 \\
41.6\end{array}$ \\
\hline 4660 & 204.0 & 9.51 & 26.43 & $\begin{array}{c}137 \mathrm{~dB} \\
139.96 \mathrm{pa}\end{array}$ & \begin{tabular}{cc}
\multicolumn{2}{c}{10.4} \\
f 19.2 \\
R 11.9
\end{tabular} & $\begin{array}{c}8.6 \\
62.5\end{array}$ & $\begin{array}{l}11.1 \\
35.7\end{array}$ \\
\hline 4657 & 242.5 & 11.31 & 31.41 & $\begin{array}{c}138 \mathrm{~dB} \\
153.95 \mathrm{pa}\end{array}$ & $\begin{array}{c}4.0 \\
\text { f } 17.2 \\
\text { R } 7.3\end{array}$ & $\begin{array}{c}5.3 \\
27.7\end{array}$ & $\begin{array}{c}6.0 \\
29.4\end{array}$ \\
\hline 4656 & 189.5 & 8.84 & 24.55 & $\begin{array}{c}138 \mathrm{~dB} \\
147.96 \mathrm{pa}\end{array}$ & $\begin{array}{c}15.2 \\
\text { f } 50.0 \\
\text { R } 19.0\end{array}$ & $\begin{array}{l}14.7 \\
31.2\end{array}$ & $\begin{array}{l}14.2 \\
50.0\end{array}$ \\
\hline 4655 & 311.0 & 14.5 & 40.29 & $\begin{array}{c}140 \mathrm{~dB} \\
195.94 \mathrm{pa}\end{array}$ & $\begin{array}{c}2.5 \\
\text { F } 18.5 \\
\text { R } 4.0\end{array}$ & $\begin{array}{c}4.0 \\
31.2\end{array}$ & $\begin{array}{c}3.3 \\
35.7\end{array}$ \\
\hline 4653 & 267.0 & 12.45 & 34.59 & $\begin{array}{c}138 \mathrm{~dB} \\
145.96 \mathrm{pa}\end{array}$ & $\begin{array}{ll} & 7.1 \\
\text { f } 14.7 \\
\text { R } 10.1\end{array}$ & $\begin{array}{c}9.3 \\
33.3\end{array}$ & $\begin{array}{c}8.3 \\
35.7\end{array}$ \\
\hline
\end{tabular}


Table 2: Maximum and minimum peak particle velocities from upper and lower bench blasts.

\begin{tabular}{|c|c|c|c|c|c|c|c|}
\hline \multicolumn{4}{|c|}{$\begin{array}{l}\text { Peak particle velocity from upper } \\
\text { bench blasts, } \mathrm{mm} / \mathrm{sec}\end{array}$} & \multicolumn{4}{|c|}{$\begin{array}{c}\text { Peak particle velocity from lower } \\
\text { bench blasts, } \mathrm{mm} / \mathrm{sec}\end{array}$} \\
\hline$\stackrel{\circ}{\mathbf{p} \text { max }}$ & $\stackrel{\circ}{\mathbf{p}} \min$ & ${\stackrel{\circ}{\mathbf{u}_{\text {s max }}}}$ & ${\stackrel{\circ}{\mathbf{u}_{\mathrm{s} \min }}}$ & $\overline{u_{\mathbf{p} \max }}$ & $\stackrel{\circ}{\mathbf{u}}_{\mathbf{p} \min }$ & ${\stackrel{\circ}{\mathbf{u}_{\mathrm{s} \max }}}$ & $\overline{\mathrm{u}_{\mathrm{s} \min }}$ \\
\hline 42.6 & 2 & 30.4 & 1.2 & 5.8 & 1.5 & 4.0 & 1.2 \\
\hline
\end{tabular}

Shear modulus has been calculated using three methods. In the first method, it has been calculated using equation (5) (based on 3-D wave propagation assumption). In the second method, equation (13) has been used for G-calculation using E obtained from equation (9) (also based on 3-D wave propagation assumption). Finally, in the third method, G has been calculated using E obtained from equation (1) (based on 1-D wave propagation assumption) and equation (13). Results of calculation show that the magnitudes of $\mathrm{G}$ calculated directly from $\mathrm{C}_{\mathrm{s}}$ almost have the same magnitudes obtained from E-calculations based on 3-D propagation assumption. On the other hand, G magnitudes based on 1-D propagation assumption are higher than those based on 3-D propagation assumption. The percentage of increase of these higher values is the same percentages of increase in $\mathrm{E}$ values based on 1-D propagation assumption. The percentage of increase in both $\mathrm{E}$ and $\mathrm{G}$, increases with increasing Poisson's ratio. Indeed, the higher calculated elastic constants will produce higher stress magnitudes. Table 4 summarizes the calculations of the dynamic field elastic constants.

Table 3: Summary of the determined $C_{p}$ and $C_{s}$ velocities for Bani Khalid Quarry

\begin{tabular}{||c|c|c|c|c||}
\hline Seismic Group Record No. and Locality & Direction & $\begin{array}{c}\text { Layer } \\
\text { No. }\end{array}$ & $\begin{array}{c}\mathrm{c}_{\mathrm{p}} \\
(\mathrm{m} / \mathrm{sec})\end{array}$ & $\begin{array}{c}\mathrm{c}_{\mathrm{s}} \\
(\mathrm{m} / \mathrm{sec})\end{array}$ \\
\hline \hline $\begin{array}{c}\text { Group (1) } \\
\text { Approximately perpendicular to building } \\
\text { boundary and upper quarry bench. }\end{array}$ & \multirow{2}{*}{$\mathrm{N} 10^{\circ} \mathrm{W}$} & 1 & 1661 & 1038 \\
\cline { 3 - 5 } & & 2 & 2480 & 1649 \\
\cline { 3 - 5 } & & 1 & 4604 & 3081 \\
\hline $\begin{array}{c}\text { Group (2) } \\
\text { Approximately parallel to building } \\
\text { boundary and upper quarry bench. }\end{array}$ & \multirow{2}{*}{$\mathrm{N}^{\circ} 5^{\circ} \mathrm{E}$} & 2 & 2838 & 1715 \\
\cline { 3 - 5 } & & 3 & 4380 & 2933 \\
\hline
\end{tabular}

\section{Stress and Strain Calculations:}

Stress and strain calculations have been carried out following Dowding's Procedure [2]. Normal strains and stresses have been calculated using equations (2) and (3) respectively. On the other hand, shear strains and stresses have been calculated using equations (6) and (7) respectively. These calculations have been carried out using maximum and minimum radial (longitudinal) \& transverse (shear) peak particle velocities measured from the upper and lower bench blasts of the quarry. Also, the minimum and maximum $\mathrm{C}_{\mathrm{p}}$ and $\mathrm{C}_{\mathrm{s}}$ magnitudes of the three seismic layers have been 
employed in the calculations. Summary of the stress and strain calculations is displayed in Tables $(\mathbf{5}, \mathbf{6})$.

Table 4: Summary of the calculations of the field dynamic elastic constants

\begin{tabular}{|c|c|c|c|c|c|c|c|c|c|c|c|}
\hline \multicolumn{12}{|c|}{ Layer 1} \\
\hline \multicolumn{2}{|c|}{ Poisson's Ratio, $v$} & \multicolumn{4}{|c|}{ YYoung's Modulus, E, $10^{4} \mathrm{~kg} / \mathrm{cm}^{2}$} & \multicolumn{6}{|c|}{ Modulus of Rigidity, $\mathrm{G}, 10^{4} \mathrm{~kg} / \mathrm{cm}^{2}$} \\
\hline \multirow[t]{2}{*}{$v_{\max }$} & \multirow[t]{2}{*}{$v_{\min }$} & \multicolumn{2}{|c|}{ Using eq. (9) } & \multicolumn{2}{|c|}{ Using eq. (1) } & \multicolumn{2}{|c|}{ Using eq. (9) \& (13) } & \multicolumn{2}{|c|}{ Using eq. (1) \& (13) } & \multicolumn{2}{|c|}{ Using eq. (5) } \\
\hline & & $E_{\max }$ & $E_{\min }$ & $E_{\max }$ & $E_{\min }$ & $\mathrm{G}_{\max }$ & $\mathrm{G}_{\min }$ & $\mathrm{G}_{\max }$ & $\mathrm{G}_{\min }$ & $\mathrm{G}_{\max }$ & $\mathrm{G}_{\min }$ \\
\hline 0.18 & 0.178 & 5.18013 & 4.88926 & 5.6246 & 5.29765 & 2.19497 & 2.07524 & 2.3833 & 2.24858 & 2.1966 & 2.0756 \\
\hline \multicolumn{12}{|c|}{ Layer 2} \\
\hline \multicolumn{2}{|c|}{ Poisson's Ratio, $v$} & \multicolumn{4}{|c|}{ Young's Modulus, E, $10^{4} \mathrm{~kg} / \mathrm{cm}^{2}$} & \multicolumn{6}{|c|}{ "Modulus of Rigidity, $\mathrm{G}, 10^{4} \mathrm{~kg} / \mathrm{cm}^{2}$} \\
\hline \multirow[t]{2}{*}{$v_{\max }$} & \multirow[t]{2}{*}{$v_{\min }$} & \multicolumn{2}{|c|}{ Using eq. (9) } & \multicolumn{2}{|c|}{ Using eq. (1) } & \multicolumn{2}{|c|}{ Using eq. (9) \& (13) } & \multicolumn{2}{|c|}{ Using eq. (1) \& (13) } & \multicolumn{2}{|c|}{ Using eq. (5) } \\
\hline & & $E_{\max }$ & $\mathrm{E}_{\min }$ & $E_{\max }$ & $E_{\min }$ & $\mathrm{G}_{\max }$ & $\mathrm{G}_{\min }$ & $\mathrm{G}_{\max }$ & $\mathrm{G}_{\min }$ & $\mathrm{G}_{\max }$ & $\mathrm{G}_{\min }$ \\
\hline 0.212 & 0.104 & 16.0020 & 13.4599 & 18.0625 & 13.7929 & 6.6015 & 6.0960 & 7.4515 & 6.2468 & 6.5956 & 6.0981 \\
\hline \multicolumn{12}{|c|}{ Layer 3} \\
\hline \multicolumn{2}{|c|}{ Poisson's Ratio, $v$} & \multicolumn{4}{|c|}{ Y Young's Modulus, E, $10^{4} \mathrm{~kg} / \mathrm{cm}^{2}$} & \multicolumn{6}{|c|}{ "Modulus of Rigidity, $\mathrm{G}, 10^{4} \mathrm{~kg} / \mathrm{cm}^{2}$} \\
\hline \multirow[t]{2}{*}{$v_{\max }$} & \multirow[t]{2}{*}{$v_{\min }$} & \multicolumn{2}{|c|}{ Using eq. (9) } & \multicolumn{2}{|c|}{ Using eq. (1) } & \multicolumn{2}{|c|}{ Using eq. (9) \& (13) } & \multicolumn{2}{|c|}{ Using eq. (1) \& (13) } & \multicolumn{2}{|c|}{ Using eq. (5) } \\
\hline & & $\overline{E_{\max }}$ & $\overline{E_{\min }}$ & $E_{\max }$ & $\overline{E_{\min }}$ & $\mathrm{G}_{\max }$ & $\mathrm{G}_{\min }$ & $\mathrm{G}_{\max }$ & $\mathrm{G}_{\min }$ & $\mathrm{G}_{\max }$ & $\mathrm{G}_{\min }$ \\
\hline 0.094 & 0.0935 & 46.6125 & 42.1931 & 47.5360 & 43.0229 & 21.3037 & 19.2927 & 21.7258 & 19.6721 & 21.2880 & 19.2919 \\
\hline
\end{tabular}

Table 5: Summary of Calculated Normal and Shear Stresses and Strains for Layer1 and layer 2, Bani Khaled Quarry

\begin{tabular}{|c|c|c|c|c|c|c|c|c|c|}
\hline \multirow{8}{*}{$\overrightarrow{\widetilde{y}}$} & \multirow{8}{*}{$\begin{array}{l}\text { Bulk density }=2000 \\
\mathrm{Kg} / \mathrm{m}^{3} \\
\mathbf{C}_{\mathbf{p} \text { max }}=1661 \mathrm{~m} / \mathrm{sec}, \\
\mathbf{C}_{\mathbf{p}_{\text {min }}}=1612 \mathrm{~m} / \mathrm{sec}, \\
\text { Cs }_{\text {max }}=1038 \mathrm{~m} / \mathrm{sec}, \\
\text { Cs }_{\text {min }}=1003 \mathrm{~m} / \mathrm{sec}\end{array}$} & \multicolumn{8}{|c|}{ Peak Particle Velocity from Upper Bench, mm/sec } \\
\hline & & \multicolumn{2}{|c|}{$\stackrel{\circ}{p \max }=42.6$} & \multicolumn{2}{|c|}{$\stackrel{\circ}{\mathbf{u}} \min =\mathbf{2}$} & \multicolumn{2}{|c|}{$\stackrel{\circ}{\mathrm{u}}$ max $_{\mathrm{max}}=30.4$} & \multicolumn{2}{|c|}{$\stackrel{\circ}{\mathrm{u} \min }_{\mathrm{s}}=\mathbf{1 . 2}$} \\
\hline & & $\begin{array}{c}\boldsymbol{\sigma}_{\max },{ }^{2} \\
\mathrm{~kg} / \mathrm{cm}^{2}\end{array}$ & $\begin{array}{l}\varepsilon_{\max }, \\
10^{-6}\end{array}$ & $\begin{array}{c}\boldsymbol{\sigma}_{\min }, \\
\mathrm{kg} / \mathrm{cm}^{2}\end{array}$ & $\begin{array}{l}\varepsilon_{\min }, \\
10^{-6}\end{array}$ & $\begin{array}{c}\tau_{\max ,} \\
\mathrm{kg} / \mathrm{cm}^{2}\end{array}$ & $\begin{array}{l}\gamma_{\max }, \\
10^{-6}\end{array}$ & $\begin{array}{c}\tau_{\min ,} \\
\mathrm{kg} / \mathrm{cm}^{2}\end{array}$ & $\begin{array}{l}\gamma_{\min ,} \\
10^{-6}\end{array}$ \\
\hline & & 1.44 & 25.6 & 0.066 & 1.24 & 0.64 & 29.29 & 0.025 & 1.19 \\
\hline & & \multicolumn{8}{|c|}{ Peak Particle Velocity from Lower Bench, mm/sec } \\
\hline & & \multicolumn{2}{|c|}{$\stackrel{\circ}{p \max }_{\mathrm{u}}=5.8$} & \multicolumn{2}{|c|}{$\stackrel{\circ}{p \min }_{\mathbf{p}}=1.5$} & \multicolumn{2}{|c|}{$\stackrel{\circ}{\mathbf{u} \text { max }}_{\mathrm{s}}=4$} & \multicolumn{2}{|c|}{$\mathrm{u}_{\mathrm{s} \min }=1.2$} \\
\hline & & $\begin{array}{c}\boldsymbol{\sigma}_{\max },{ }^{2} \\
\mathrm{~kg} / \mathrm{cm}^{2}\end{array}$ & $\begin{array}{l}\varepsilon_{\max }, \\
10^{-6}\end{array}$ & $\begin{array}{c}\boldsymbol{\sigma}_{\text {min }} \\
\mathrm{kg} / \mathrm{cm}^{2}\end{array}$ & $\begin{array}{l}\boldsymbol{\varepsilon}_{\min }, \\
10^{-6}\end{array}$ & $\underset{\mathrm{kg} / \mathrm{cm}^{2}}{\tau_{\text {max, }}}$ & $\begin{array}{l}\gamma_{\text {max }}, \\
10^{-6}\end{array}$ & $\begin{array}{c}\tau_{\min ,} \\
\mathrm{kg} / \mathrm{cm}^{2}\end{array}$ & $\begin{array}{c}\gamma_{\min }, \\
10^{-6}\end{array}$ \\
\hline & & 1.9 & 3.5 & 0.049 & 0.93 & 0.085 & 3.8 & 0.025 & 1.19 \\
\hline \multirow{8}{*}{ 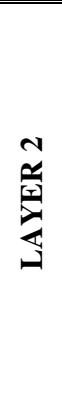 } & \multirow{8}{*}{$\begin{array}{l}\text { Bulk density }=2200 \\
\mathrm{Kg} / \mathrm{m}^{3} \\
\mathbf{C}_{\mathbf{p}_{\text {max }}}=2838 \mathrm{~m} / \mathrm{sec} \\
\mathbf{C}_{\mathbf{p}_{\text {min }}}=2480 \mathrm{~m} / \mathrm{sec} \\
\mathbf{C s}_{\text {max }}=1715 \mathrm{~m} / \mathrm{sec} \\
\mathbf{C s}_{\min }=1649 \mathrm{~m} / \mathrm{sec}\end{array}$} & \multicolumn{8}{|c|}{ Peak Particle Velocity from Upper Bench, mm/sec } \\
\hline & & \multicolumn{2}{|c|}{$\stackrel{\circ}{\mathrm{u} \max }_{\mathrm{u}}=42.6$} & \multicolumn{2}{|c|}{$\stackrel{\circ}{\mathrm{p} \min }_{\mathrm{z}}=\mathbf{2}$} & \multicolumn{2}{|c|}{$\stackrel{\mathrm{u}}{\mathrm{s} \max }_{\mathrm{s}}=\mathbf{3 0 . 4}$} & \multicolumn{2}{|c|}{$\mathrm{u}_{\mathrm{s} \min }=\mathbf{1 . 2}$} \\
\hline & & $\begin{array}{r}\boldsymbol{\sigma}_{\max },{ }^{2} \\
\mathrm{~kg} / \mathrm{cm}^{2}\end{array}$ & $\begin{array}{l}\varepsilon_{\max }, \\
10^{-6} \\
\end{array}$ & $\begin{array}{c}\boldsymbol{\sigma}_{\text {min }}, \\
\mathrm{kg} / \mathrm{cm}^{2}\end{array}$ & $\begin{array}{c}\boldsymbol{\varepsilon}_{\min } \\
10^{-6} \\
\end{array}$ & $\begin{array}{r}\tau_{\max ,},{ }_{2} \\
\mathrm{~kg} / \mathrm{cm}^{2}\end{array}$ & $\begin{array}{l}\gamma_{\text {max }}, \\
10^{-6} \\
\end{array}$ & $\begin{array}{c}\tau_{\min },{ }^{2} \\
\mathrm{~kg} / \mathrm{cm}^{2}\end{array}$ & $\begin{array}{c}\gamma_{\min }, \\
10^{-6} \\
\end{array}$ \\
\hline & & 2.71 & 15.01 & 0.11 & 0.806 & 1.17 & 17.73 & 0.044 & 0.728 \\
\hline & & \multicolumn{8}{|c|}{ Peak Particle Velocity from Lower Bench, mm/sec } \\
\hline & & \multicolumn{2}{|c|}{$\bar{u}_{\mathrm{p} \max }=5.8$} & \multicolumn{2}{|c|}{$\mathbf{u}_{\mathbf{p} \min }=1.5$} & \multicolumn{2}{|c|}{${\stackrel{\circ}{\mathbf{u}_{\mathrm{s} \text { max }}}}=4$} & \multicolumn{2}{|c|}{$\mathbf{u}_{\mathrm{s} \min }=1.2$} \\
\hline & & $\begin{array}{r}\boldsymbol{\sigma}_{\max },{ }^{2} \\
\mathrm{~kg} / \mathrm{cm}^{2}\end{array}$ & $\begin{array}{l}\varepsilon_{\max }, \\
10^{-6}\end{array}$ & $\begin{array}{c}\boldsymbol{\sigma}_{\text {min }}, \\
\mathrm{kg} / \mathrm{cm}^{2}\end{array}$ & $\begin{array}{l}\varepsilon_{\min }, \\
10^{-6} \\
\end{array}$ & $\begin{array}{c}\boldsymbol{\tau}_{\max }{ }_{\mathrm{kg}}{ }_{\mathrm{kg}} \\
\end{array}$ & $\begin{array}{l}\gamma_{\text {max }}, \\
10^{-6} \\
\end{array}$ & $\begin{array}{c}\tau_{\min },{ }^{2} \\
\mathrm{~kg} / \mathrm{cm}^{2}\end{array}$ & $\begin{array}{l}\gamma_{\min }, \\
10^{-6}\end{array}$ \\
\hline & & 0.3697 & 2.04 & 0.083 & 0.605 & 0.154 & 2.33 & 0.044 & 0.73 \\
\hline
\end{tabular}




\section{Table 6: Summary of Calculated Normal and Shear Stresses and Strains for Layer 3, Bani Khaled Quarry.}

\begin{tabular}{|c|c|c|c|c|c|c|c|c|}
\hline & $\begin{array}{l}\text { Bulk der } \\
\text { Cs }_{\text {max }}=\end{array}$ & $\begin{array}{l}y=22 \\
81 \mathrm{~m} / \mathrm{s}\end{array}$ & $\begin{array}{l}\mathrm{Kg} / \mathrm{m}^{3}, \\
\mathbf{C s}_{\text {min }}\end{array}$ & $\begin{array}{l}\mathrm{x}=4 \\
33 \mathrm{~m} /\end{array}$ & $\mathrm{m} / \mathrm{sec}$, & $\min =$ & $80 \mathrm{~m} / \mathrm{se}$ & \\
\hline & & Pea & Particle & ocity f & m Uppe & 3ench, & $\mathrm{m} / \mathrm{sec}$ & \\
\hline & $\stackrel{\circ}{\mathbf{u}}_{\mathbf{p} \text { max }}$ & 42.6 & & & ${\stackrel{\circ}{\mathbf{u}_{\mathrm{s} \mathrm{ma}}}}$ & 30.4 & $\stackrel{\circ}{\mathbf{u}}_{\mathrm{s} \mathrm{n}}$ & 1.2 \\
\hline$\underline{a}$ & $\underset{\mathrm{kg} / \mathrm{cm}^{2}}{\boldsymbol{\sigma}_{\max }}$ & $\begin{array}{l}\boldsymbol{\varepsilon}_{\max }, \\
10^{-6}\end{array}$ & $\begin{array}{l}\boldsymbol{\sigma}_{\text {min }}{ }^{2} \\
\mathrm{~kg} / \mathrm{cm}^{2}\end{array}$ & $\begin{array}{l}\boldsymbol{\varepsilon}_{\min }, \\
10^{-6}\end{array}$ & $\underset{\mathrm{kg} / \mathrm{cm}^{2}}{\boldsymbol{\tau}_{\max }}$ & $\begin{array}{c}\gamma_{\max }, \\
10^{-6}\end{array}$ & $\underset{\mathrm{kg} / \mathrm{cm}^{2}}{\tau_{\min }}$ & $\begin{array}{c}\gamma_{\min }, \\
10^{-6}\end{array}$ \\
\hline$\pi$ & 4.4 & 9.25 & 0.196 & 0.457 & 2.1 & 9.87 & 0.079 & 0.41 \\
\hline- & & Pea & article & ocity f & Lowe & Bench, & $\mathrm{m} / \mathrm{sec}$ & \\
\hline & $\stackrel{\circ}{\mathbf{p}}_{\mathbf{p a z}}$ & $=5.8$ & $\stackrel{\circ}{\mathbf{u}}_{\mathbf{p}}$ & 1.5 & $\stackrel{\circ}{\mathbf{u}}_{\mathrm{s}}$ & $=4$ & $\stackrel{\circ}{\mathbf{u}} \mathbf{m}$ & 1.2 \\
\hline & $\begin{array}{c}\boldsymbol{\sigma}_{\max },{ }^{2} \\
\mathrm{~kg} / \mathrm{cm}^{2}\end{array}$ & $\begin{array}{l}\boldsymbol{\varepsilon}_{\max }, \\
10^{-6}\end{array}$ & $\begin{array}{c}\boldsymbol{\sigma}_{\text {min }} \\
\mathrm{kg} / \mathrm{cm}^{2}\end{array}$ & $\begin{array}{l}\boldsymbol{\varepsilon}_{\min }, \\
10^{-6}\end{array}$ & $\begin{array}{l}\boldsymbol{\tau}_{\max }, \\
\mathrm{kg} / \mathrm{cm}^{2}\end{array}$ & $\begin{array}{c}\gamma_{\max }, \\
10^{-6}\end{array}$ & 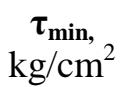 & $\begin{array}{l}\gamma_{\min }, \\
10^{-6}\end{array}$ \\
\hline & 0.60 & 1.26 & 0.15 & 0.34 & 0.28 & 1.3 & 0.079 & 0.41 \\
\hline
\end{tabular}

\section{CONCLUSIONS AND RECOMMENDATIONS}

This paper aims to illustrate the procedure of calculating strains and stresses induced by ground blasting vibrations using both measured peak particle and propagation velocities. From the results of the performed measurements, calculations, and analyses some conclusions and recommendations have been drawn:

1. Shallow seismic refraction surveys have been carried out in Bani Khalid quarry to determine the velocity of compression and shear waves at the quarry area. Two bedding planes separating three layers have been depicted. The seismic velocities have been found to range from 1661 to $4380 \mathrm{~m} / \mathrm{sec}$ for $\mathrm{C}_{\mathrm{p}}$ and from 1038 to 2933 for $\mathrm{C}_{\mathrm{s}}$.

2. Measurement of the peak particle velocities from the upper bench blasts have shown radial components ranged from 2 to $42.6 \mathrm{~mm} / \mathrm{sec}$ and from 1.2 to 30.4 $\mathrm{mm} / \mathrm{sec}$ for the transverse component. Measurement of the peak particle velocities from the lower bench blasts have shown radial components ranging from 1.5 to $5.8 \mathrm{~mm} / \mathrm{sec}$ and from 1.2 to $4 \mathrm{~mm} / \mathrm{sec}$ for the transverse component.

3. The field dynamic elastic constants of the quarry area have been determined. Poisson's ratio ranged from 0.0935 to 0.212 , Young's modulus ranged from $4.8892 \times 10^{4}$ to $47.536 \times 10^{4} \mathrm{~kg} / \mathrm{cm}^{2}$, and shear modulus ranged from 2.0752 $\mathrm{x} 10^{4}$ to $21.7258 \times 10^{4} \mathrm{~kg} / \mathrm{cm}^{2}$.

4. The determined normal stresses and strains have a range from 0.049 to 4.4 $\mathrm{kg} / \mathrm{cm}^{2}$ for stresses, while strains range from $0.34 \times 10^{-6}$ to $25.6 \times 10^{-6}$.

5. The determined shear stresses and strains have a range from 0.025 to 2.1 $\mathrm{kg} / \mathrm{cm}^{2}$ for stresses, while strains range from $0.079 \times 10^{-6}$ to $29.29 \times 10^{-6}$.

6. It is recommended that for high-magnitude Poisson's ratio, calculation of E, G, stresses, and strains should be calculated on the 3-D wave propagation basis. That is because the calculation error increases with increase in Poisson's ratio. 
7. It is recommended that the environmental authorities make obligatory regulations for ground vibration measurements. That is important, especially for the mining activities using blasting operations nearby residential areas to assure safety and prevent damage to these national investments.

\section{AKNOWLEDEGMENTS}

The authors wish to express their gratitude to the staff of the Egyptian Iron and Steel Company, Sector of Bani Khalid, for their accommodation, help, and co-operation. Special thanks are due to Eng. Hasanien A. Hasanien and his blasting team for their efforts and sincere co-operation.

\section{REFERENCES}

1. Atlas of Powder Company, "Explosives and rock blasting", Field Tech. Operations", Atlas Powder Co., Dallas, Texas USA, pp.321-411, (1987).

2. Dowding, Charles, "Ground vibration monitoring and control", Prentice Hall, USA, 297 p., (1985).

3. Siskind, D. E., Stagg, M. S., Kopp, J. W., and Dowding, C. H., "Structure response and damage produced by ground vibration from surface Mine blasting", RI 8507, USBM, 74 p., (1980).

4. Reynolds, J. M., "An introduction to applied and environmental geophysics", John Wiley \& Sons, Chichester, England, 796p., (1997).

5. Sheriff, R. E. and Geldart, L. P., "Exploration seismology, vol. 1: History, theory and data acquisition", Cambridge University Press, Cambridge, 253p., (1982).

6. Dobrin, M. B., "Introduction to geophysical prospecting", 3rd Ed., McGraw-Hill International Book Co., 630 p., (1976).

7. Coates, D. F., "Rock mechanics principles", Monograph 874, CANMET Energy, Mines, and Resources Canada, Ottawa, Canada, Ch. 8, (1981).

8. Burgher, K. E., "P-wave and S-wave velocity measurement for stress-strain analysis", 15th Conf. on Expl. and Blasting Tech., SEE, Ohio, USA, pp. 87-96, (1979).

9. Tealeb, A. A.; Sobaih, M. E.; Mohamed, A. A., and Abdel-Rahman, K., "Stress level estimation for the ground beneath the 15TH of May city buildings, Helwan, Cairo, Egypt", Int. Conf. for Environmental Hazard Mitigation, Center of Environmental Hazard Mitigation, Cairo University, Cairo, Egypt, 29 p., September 9-12, (2000).

10. Tealeb, A. A.; Sobaih, M. E.; Mohamed, A. A., and Abdel-Rahman, K., "Stress level estimation for the ground beneath the 15TH of May city buildings, Helwan, Cairo, Egypt”, ACTA Geod. Geoph., Vol. 38 (4), Budapest, Hungary, pp. 429443, (2003).

11. Tealeb, A. A.; Sobaih, M. E.; Mohamed, A. A., and Abdel-Rahman, K., “ Determination of the safe distance between quarry blasting and buildings", NRIAG, J. of Geophysics, Vol. 2, No. 1, pp. 143-160, (2003). 
12. Abdel-Fattah A. M. Kolali, "On choice of optimum parameters of drilling and blasting operations for the Beni Khalid quarry", Diploma Thesis, Ming. Eng. Dept., El-Tabbin Institute for Metallurgical Studies, El-Tabbin, Egypt, 154 p., (1977).

13. EG\&G Geometrics, "SeisView-Seismic Refraction Processing Software", User's Manual, Geometrics, Inc., Sunnyvale, USA, 50p., (1986).

14. GeoSonics Inc., "Operation guide for SSU Micro-seismograph and MicroInterrogator, " Manual Ver. 941201, GeoSonics Inc., P. O. Box 779, Warrendale, $\mathrm{Pa}$.

15. GeoSonics Inc., "Operation guide for the SSU-2000 DK Seismograph", Manual Ver. 931001y, GeoSonics Inc., P. O. Box 779, Warrendale, Pa.[16] Abdel-Rasoul, E. I., " Measurement and analysis of the effect of ground vibrations induced by blasting at the limestone quarries of the Egyptian Cement Company", Int. Conf. for Environmental Hazard Mitigation, Center of Environmental Hazard Mitigation, Cairo University, Cairo, Egypt, 15 p., (2000).

16. Abdel-Rasoul, E. I., "Assessment of the particle velocity characteristics of blasting vibrations at Bani Khalid quarries", Bulletin of the Faculty of Engineering, Assiut University, Assiut, Egypt, pp. 135-150, (2000).

\section{تقدير مستوى الاجهادات والانفعالات الناتجة عن اهتزازات التفجير باستخدام السرعات المقاسة للجزيئات وللانتشار في محاجر بني خالد}

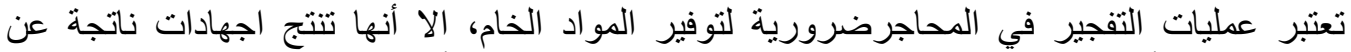

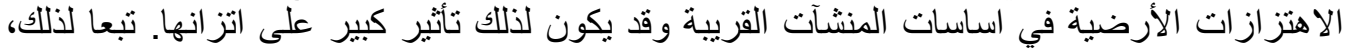

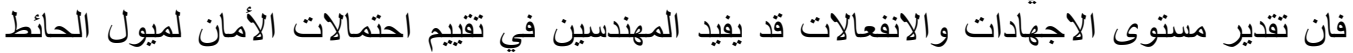

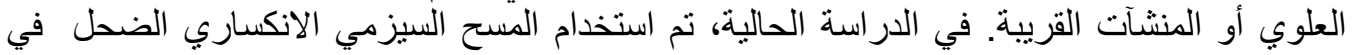

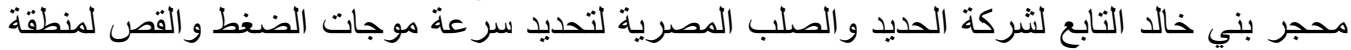

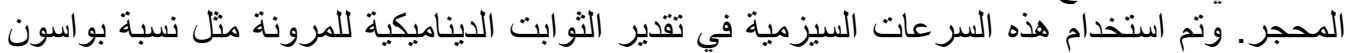

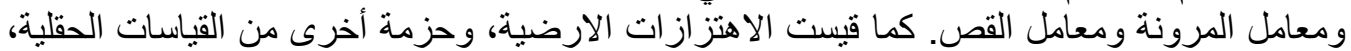

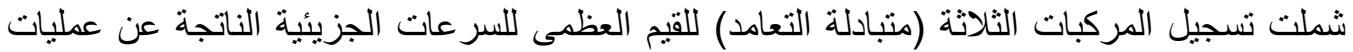

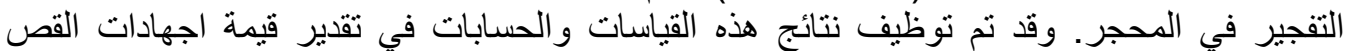

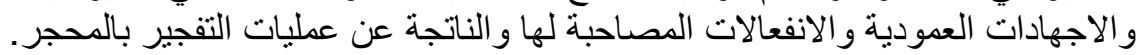

